\title{
Characteristics of dairy productivity of Holstein heifers depending on their genetic potential
}

\author{
Tahir M. Akhmetov ${ }^{1, *}$, Natalia Yu. Safina ${ }^{1,2}$, and Shamil K. Shakirov ${ }^{2}$ \\ ${ }^{1}$ Kazan State Academy of Veterinary Medicine named after N.E. Bauman, Kazan 420029, Russia \\ ${ }^{2}$ Tatar Scientific and Research Institute of Agriculture - Subdivision of the Federal State Budgetary Institution of Science "Kazan \\ Scientific Center of Russia Academy of Sciences, Kazan 420059, Russia
}

\begin{abstract}
The study presents the results obtained in DNA testing of allelic polymorphism by PCR-RFLP based methods for the leptin and stearoyl-coenzyme A desaturase genes and the interaction of their complex genotypes on the milk productivity indicators of Holstein heifers of Tatarstan population. The study was carried out among 471 Holstein cow-heifers by Integrated Agricultural Production Centre "Stud farm named after Lenin" of Atninsky district of the Republic of Tatarstan in 2016-2018. All complex LEP/SCD1 genotypes were identified through the study. The maximum frequency was observed in the combination of heterozygous genotypes LEPTCSCD1TC - 149 animals $(31.5 \%)$. Milk productivity test, based on the complex genotypes LEP and SCD1, showed that a significantly high level of productivity for 305 days of lactation was $7314.4 \mathrm{~kg}$, and in heifers with a complex genotype LEPTTSCD1CC was minimal $(6337.4 \mathrm{~kg})$ in comparison with indicators of milk yield of heifers with other complex genotypes. According to the content of the mass fraction of fat, reliably the best indicators were established in a subpopulation of animals with a complex TT/TC genotype $-3.87 \%$. The content of the mass fraction of protein was maximal for animals with a complex CC/CC genotype.
\end{abstract}

\section{Introduction}

DNA testing can be used to determine if an animal is a "carrier" of a particular trait. Each trait develops under the influence of many genes interacting at the organism level [1]. Most of the traits of economic importance for dairy cattle (milk yield, the content of the mass fraction of fat and protein, etc.) are limited by gender and can be assessed only in females.

The expression of genes involved in insulin resistance can induce apoptosis of the transcription factor via the mitochondrial pathway. It is positive that leptin (LEP) is involved in the regulation of the activity of the enzyme stearoyl-CoA desaturase (SCD), as a feedback peptide in the regulation of visceral fat cell function at the body level. Under the action of insulin in the cells of a living organism, the expression of the enzyme stearoyl-coenzyme

A desaturase converts glucose C16: 0 palmitic to C18:0 stearic unsaturated fatty acid. Next, stearic acid is converted C18: 1 to $\omega-9$ oleic monounsaturated fatty acid. Oleic metabolism is more effective than palmitic. This ensures the maximum performance of mitochondria in the synthesis of ATP and the supply of energy substrates for all biological functions.

At the beginning of lactation, dairy cows are in a state of negative energy balance - the process when fat reserves and feed consumption are directed to the energy-intensive process of lactogenesis [2, 3].
Lipids, including triglycerides, cholesterol and phospholipids, as well as their derivatives, provide the body with energy and play a significant role in the functioning of the endocrine system and some intracellular signaling pathways.

Leptin is supposedly necessary for the growth, development and functioning of the mammary gland, despite the fact that this requires the expression of prolactin, which then interacts with leptin to affect its activity [4].

The bovine leptin gene (LEP) is mapped on chromosome 4q32, has a length of $16.735 \mathrm{~kb}$, covers 3 exons and encodes a protein of 167 amino acids, which includes a signal sequence of 21 amino acids [5, 6].

Leptin is of interest to selection due to the fact that it largely determines the milk productivity of livestock, the content of components in milk (protein and fat), and, equally important, it is associated with productive longevity of farm animals $[7,8]$.

Steaoryl CoA desaturase (SCD) is an endoplasmic reticular enzyme responsible for the $\Delta 9$-desaturation of fatty acids (FA) in the mammary gland, adipose and other tissues, by introducing a double bond in the delta-9 position in the acyl-coenzymes A substrates $[9,10]$.

The functional role of SCD expression and the conversion of palm rich fatty acid to oleic monounsaturated fatty acid are recognized worldwide. This process is necessary for the physiological metabolism of lipids and fatty acids, the formation of

* Corresponding author: ahmetov-tahir@mail.ru 
substrates for the production of energy by cells, the formation of oleic triglycerides and the physiological mobilization of ATP synthesis.

The gene encoding SCD1 consists of 6 exons and 5 introns, located on 26 bovine chromosomes [12], where some QTLs responsible for fertility, fat content, milk yield and other quantitative traits were also identified $[13,14]$.

DNA diagnostics of polymorphism of genes associated with the same sign of milk productivity in a complex can be considered more effective than the study of each gene separately [15].

The purpose of this research was to study the relationship of complex genotypes LEP and SCD1 with indicators of milk productivity of Holstein heifers.

\section{Materials and methods}

In the course of the study, 471 first-calf cows of the Holstein breed Integrated Agricultural Production Centre "Stud farm named after Lenin" Atninsky district of the Republic of Tatarstan were selected samples of biological material. Blood extraction was carried out using the AmpliPrim DNA-sorb B kit (InterLab, Russia), according to the manufacturer's instructions.

To analyze the SNP of exon 2 of the leptin gene (LEP), the AC - PCR method was used according to the protocol developed under the guidance of E. Armstrong [14]. This system is based on the use of four primers LEP-F1 + LEP-R1 and LEP-F2 + LEP-R2, two external ones that limit amplification to the gene region where the mutation is located, and two internal ones that generate a second variable-size amplicon, depending from which allele $\mathrm{C}$ or $\mathrm{T}$ hybridized its end 3 '.

To increase the specificity of the reaction, a change in the basic position (mismatch) is introduced between the first and third positions to the 3'-end of the "internal" primers. Both alleles are amplified simultaneously, and then identified by the size of their fragments in gel electrophoresis $[15,16]$.

The reaction mixture consisted of primers with the following oligonucleotide sequence (SibEnzyme, Russia):

\section{F1: 5' - GACGATGTGCCACGTGTGGTTTCTTCTGT - 3' R1: 5' - CGGTTCTACCTCGTCTCCCAGTCCCTCC - 3' F2: 5' - TGTCTTACGTGGAGGCTGTGCCCAGCT - 3' R2: 5' - AGGGTTTGGGTGTCATCCTGGACCTTTCG - 3'.}

To identify the SCD1 gene polymorphism, testing was performed by the method of polymerase chain reaction with subsequent analysis of the lengths of restriction fragments according to the protocol developed by M. Taniguchi et al., 2004 [17].

Amplification was carried out in optimal temperature-time conditions on the device "T100 ThermalCycler" (Bio-Rad, USA) with the introduction of oligonucleotide primers (Evrogen, Russia) into the reaction mixture containing purified DNA of experimental animals:
F: 5' - ATGTATGGATACCGCCCTTATGAC - 3'

R: 5' - TTCTGGCACGTAACCTAATACCCTAAGC - 3',

Hydrodysis of SCD1 gene fragments obtained during amplification was performed for 16 hours at $37^{\circ} \mathrm{C}$ in the presence of the restriction endonuclease Fsp4H I (SibEnzyme, Russia) according to the manufacturer's instructions.

The electrophoretic separation of the restriction fragments obtained during the reactions was carried out by means of a horizontal forecore in an agarose gel of $2.6 \%$ in the presence of ethidium bromide at $20 \mathrm{~W}$ for 20 minutes. Visualization and video fixation was performed in the gel-documentation system Gel \& Doc (Bio-Rad, USA).

The study also used data on the herd, obtained from the official electronic database "SELEX. Dairy cattle" (AWP Plinor, Russia). Statistical calculations were performed using biometric analysis formulas, the reliability and significance of the results were evaluated by the t-student criterion [18].

\section{Results and discussion}

The whole fragment of the SCD1 gene and the products of the LEP gene were successfully amplified by PCR and AC-PCR. The obtained whole fragment of the SCD1 gene had $145 \mathrm{bp}$, and was subsequently digested with the restriction endonuclease Fsp4H I.

During the hydrolysis, base pairs having the following sizes were obtained: $\mathrm{CC}-29,48$ and $68 \mathrm{bp}$, TC - 29, 48, 68 and $116 \mathrm{bp}, \mathrm{TT}-29$ and $116 \mathrm{bp}$. According to the results of DNA testing of cattle by the LEP gene, the following number of bases represented the genotypes: CC - 164 and 239 bp; TC - 131, 164 and 239 bp; TT -131 and $239 \mathrm{bp}$.

The frequency of complex genotypes indicated in the table shows the predominance of the number of animals with heterozygous genotypes for both studied $\mathrm{LEP}^{\mathrm{TC}} \mathrm{SCD} 1^{\mathrm{TC}}$ genes, and makes up more than $30 \%$ of the total population studied.

The minimum number of specimen is represented by a subpopulation with homozygous TT/TT genotypes for the LEP and SCD1 gene loci $-1.9 \%$ (9 animals).

As a result of the genotyping of Holstein heifers, all alleles and genotypes of the LEP and SCD1 genes were identified. All combinations of complex genotypes of the indicated genes were identified (Table 1).

Heifers with a complex genotype $\mathrm{LEP}^{\mathrm{TT}} \mathrm{SCD} 1^{\mathrm{CC}}$ had the advantage of a total milk yield for 305 days of lactation over heifers with other genotypes. The significant difference between groups with complex genotypes LEP/SCD1 was: TT/CC and CC/TC $574.9 \mathrm{~kg}(7.9 \% ; \mathrm{p} \leq 0.05), \mathrm{TT} / \mathrm{CC}$ and $\mathrm{TC} / \mathrm{TC}-977.0 \mathrm{~kg}$ (13.4\%; $\leq \leq 0.01), \mathrm{TT} / \mathrm{CC}$ and TT/TC $-730.5 \mathrm{~kg}$ $(10.0 \% ; \mathrm{p} \leq 0.05)$.

In a number of experiments, it was reported that animals carrying the homozygous $\mathrm{T}$ allele at the locus of the leptin gene produce more milk with high protein content $[19,20]$.

Low milk yields, as well as an insufficient content of the mass fraction of protein and fat, were recorded in 
individuals with the heterozygous TC genotype of the leptin gene [21].

In studies of the Italian Holstein cattle population N. Macciotta et al. (2008) found that SCD1 gene polymorphism affects milk yield and milk protein yield.
Cows with the TT genotype had more milk and milk protein compared to cows with the CC genotype [22].

M. Pozovnikova et al. (2017) in their work noted a significant superiority in milk yield and milk yield of animals with the SCD1 CC genotype over peers with the TC and TT genotypes [23].

Table 1. Milk productivity of heifers with complex genotypes LEP/SCD1

\begin{tabular}{|c|c|c|c|c|c|c|}
\hline \multirow{2}{*}{$\begin{array}{l}\text { Genotypes } \\
\text { LEP/SCD1 }\end{array}$} & \multirow{2}{*}{$\begin{array}{l}\mathrm{N}=471 \\
\mathrm{n}(\%)\end{array}$} & \multirow{2}{*}{$\begin{array}{c}\text { Milk yield for } 305 \text { days, } \\
\mathrm{kg}\end{array}$} & \multicolumn{2}{|c|}{ Mass fraction, $\%$} & \multicolumn{2}{|c|}{ Yield, kg } \\
\hline & & & fat & protein & fat & protein \\
\hline $\mathrm{CCCC}$ & $39(8.3)$ & $6981.5 \pm 147.5$ & $3.57 \pm 0.12$ & $3.39 \pm 0.05$ & $249.2 \pm 10.6$ & $236.6 \pm 6.1$ \\
\hline ССТC & $75(15.8)$ & $6568.6 \pm 131.2^{*}$ & $3.75 \pm 0.08$ & $3.24 \pm 0.04 *$ & $246.6 \pm 6.6$ & $213.1 \pm 5.6^{* *}$ \\
\hline CCTT & $19(3.9)$ & $6739.5 \pm 289.6$ & $3.68 \pm 0.13$ & $3.28 \pm 0.04$ & $247.9 \pm 15.3$ & $221.3 \pm 11.0$ \\
\hline TCCC & $73(15.4)$ & $7109.7 \pm 126.7$ & $3.54 \pm 0.08 *$ & $3.34 \pm 0.03$ & $251.6 \pm 7.3$ & $237.8 \pm 5.0$ \\
\hline TCTC & $149(31.5)$ & $6337.4 \pm 98.4^{* *}$ & $3.83 \pm 0.06$ & $3.20 \pm 0.02 * * *$ & $242.6 \pm 4.6$ & $202.8 \pm 3.9^{* * *}$ \\
\hline TCTT & $29(6.1)$ & $6839.4 \pm 272.1$ & $3.39 \pm 0.12 * *$ & $3.29 \pm 0.05$ & $231.7 \pm 10.9$ & $225.0 \pm 9.8$ \\
\hline TTCC & $22(4.7)$ & $7314.4 \pm 313.2$ & $3.59 \pm 0.15$ & $3.24 \pm 0.05^{*}$ & $262.5 \pm 16.2$ & $237.0 \pm 12.6$ \\
\hline TTTC & $59(12.4)$ & $6583.9 \pm 162.6^{*}$ & $3.87 \pm 0.11$ & $3.21 \pm 0.03 * *$ & $254.8 \pm 7.7$ & $211.5 \pm 6.5^{* * *}$ \\
\hline TTTT & $9(1.9)$ & $6734.1 \pm 434.7$ & $3.51 \pm 0.19$ & $3.28 \pm 0.07$ & $236.6 \pm 19.9$ & $221.1 \pm 16.2$ \\
\hline
\end{tabular}

The increased content of the fat mass fraction in milk was observed in animals with the TT/TC complex genotype, a significant difference with the TC/CC and TC/TT genotypes was 0.33 and $0.48 \%$, respectively. In general, according to the results of the analysis of the content of the fat mass fraction, specimen with the heterozygous genotype SCD $1^{\mathrm{TC}}$ genotype in the complex genotype were distinguished by an increased fat content in the milk produced (Table 1).

Researchers studying the SCD1 gene described a significant effect on the percentage of fat, but did not confirm the effect on other signs of milk productivity in Holstein cattle [24].

The maximum content of the mass fraction of protein in the studied groups was found in heifers with homozygous complex genotypes $\mathrm{LEP}^{\mathrm{CC}} \mathrm{SCD} 1^{\mathrm{CC}}$ and was $3.39 \%$, which significantly exceeds the results obtained from heifers with genotypes $\mathrm{CC} / \mathrm{TC}, \mathrm{TC} / \mathrm{TC}, \mathrm{TT} / \mathrm{CC}$, TT/TC on $0.15 \%(\mathrm{p} \leq 0.05), 0.19 \%(\mathrm{p} \leq 0.001), 0.15 \%$ $(\mathrm{p} \leq 0.05)$ and $0.18 \%(\mathrm{p} \leq 0.01)$, respectively.

Animals with the complex genotype TC/CC differed favorably from peers with other genotypes in the yield of milk fat. The difference in this indicator between them and specimen with the worst result (TC/TT) was $30.8 \mathrm{~kg}$ $(11.7 \%)$.

The maximum level of milk protein was observed in animals with the complex genotype TC/CC. The superiority of heifers with the $\mathrm{LEP}^{\mathrm{TC}} \mathrm{SCD} 1^{\mathrm{CC}}$ genotype in the yield of milk protein was $24.7 \mathrm{~kg}(1.4 \%$; $\mathrm{p} \leq 0.01)$ over the heifers with the CC/TC genotype, $35.0 \mathrm{~kg}(14.7$ $\%$; over TC/TC); $\mathrm{p} \leq 0.001)$ and over TT/TC $-26.3 \mathrm{~kg}$ (11.1\%; $\leq \leq 0.01)$. P.M. Kgwatalala et al. (2009), who studied the polymorphism of the SCD1 gene, found that milk yield for lactation and protein yield in cows with the CC genotype are higher than in cows with the TT genotype [25].
However, there are a number of experiments in which the effects of the influence of SCD1 genotypes on milk yield and the qualitative composition of milk have not been established [26, 27].

Thus, according to the main indicators of milk productivity, specimen bearing in the complex genotype the allele $\mathrm{T}$ of the leptin gene (LEP) and the homozygous allele $\mathrm{C}$ of the stearoyl-CoA desaturase (SCD) genetically distinguished themselves. The content of the mass fraction of protein was maximal in animals with a complex $\mathrm{CC} / \mathrm{CC}$ genotype.

\section{Conclusion}

The significant associations identified in this study may support the development of a breeding program that uses molecular information about the LEP and SCD1 gene loci to genetically evaluate animals for milk production and milk quality. The results are based on data obtained during DNA testing of 471 cows, which indicates the representativeness of the sample and the statistical reliability of the results.

Therefore, when selecting animals for marker auxiliary selection (MAS) for increase in milk yield and milk fat should be paid attention to animals with the allele $\mathrm{T}$ gene of leptin (LEP) and the homozygous gene $\mathrm{C}$ of desaturase (SCD) in the complex genotype, and when breeding for protein milk content, with homozygous CC/CC complex genotypes.

\section{Acknowledgments}

This research was supported by FASO Russia project AAAA-A18-118031390148-1. 


\section{References}

1. N. Zinoveva, P. Klenovitski, E. Gladyr, A. Nikichov, Modern methods of genetic control of breeding processes and certification of breeding material in animal husbandry: a training manual (Moscow, 2008)

2. L.M. Chagas, J.J. Bass, D. Blache, C.R. Burke, J.K. Kay, D.R. Lindsay, M.C. Lucy, G.B. Martin, S. Meier, F.M. Rhodes, J. of Dairy Sci. 90, 4022-4032 (2007)

3. N. Safina, Sh. Shakirov, F. Zinnatova, Z. Fattakhova, E. Gaynutdinova, L. Shayakhmetova, Research J. of Pharmaceut., Biolog. and Chem. Sci. 9(6), 2028-2031 (2018)

4. Y. Feuermann, S.J. Mabjeesh, L. Niv-Spector, D. Levin, A. Shamay, J. of Endocrinol. 191, 407413 (2006)

5. D. Pomp, T. Zou, A.C. Clutter, W. Barendse, J. of Animal Sci. 75, 1427 (1997)

6. Y. Taniguchi, T. Itoh, T. Yamada, Y. Sasaki, IUBMB Life 53, 131-135 (2002)

7. T. Van der Lende, M.F. Te Pas, R.F. Veerkamp, S.C. Liefers, Vitamine Hormone 71, 373-404 (2005) DOI: 10.1016/S0083-6729(05)71013-X

8. S. Tjulkin, T. Ahmetov, A. Muratova, R. Vafin, Actual Quest. of Veter. Biology 1(17), 27-30 (2013)

9. P.C. Garnsworthy, S. Feng, A.L. Lock, M.D. Royal, Dairy Sci. 93, 1743-1748 (2010)

10. H. Kulig, I. Kowalewska-Łuczak, K. Zukowski, M. Kunicka, Acta Scientiarium Polonorum, Zootechn. 12(1), 41-48 (2013)

11. E.M. Campbell, D.S. Gallagher, S.K. Davis, J. Animal Sci. 79, 1954-1995 (2001)

12. C.A. Morris, C.D. Bottema, N.G. Cullen, S.M. Hickey, A.K. Esmailizadeh, B.D. Siebert, W.S. Pitchford, Animal Genet. 41, 589-596 (2010)

13. J.K. Höglund, B. Guldbrandtsen, G. $\mathrm{Su}, \mathrm{B}$. Thomsen, M.S. Lund, J. of Dairy Sci. 92, 21362143 (2009) DOI: 10.3168/jds.2008-1104
14. E. Armstrong, F. Peñagaricano, R. Artigas, L. De Soto, C. Corbi, S. Llambí, G. Rincón, A. Postiglioni, Archivos de Zootecn. 60(231), 707-716 (2011)

15. S. Ye, S. Dhillon, X. Ke, A. Collins, I. Day, Nucleic Acids Res. 29, 88e (2001)

16. X.-L. Wu, M.D. MacNeil, S. De, Q.-J. Xiao, J.J. Michal, Ch.T. Gaskins, J.J. Reeves, J.R. Busboom, R.W. Wright Jr., Z. Jiang, Genetica 125, 103-113 (2005) DOI 10.1007/s10709-005$5255-1$

17. M. Taniguchi, T. Utsugi, K. Oyama, H. Mannen, M. Kobayashi, Y. Tanabe, A. Ogino, S. Tsuji, Mammalian Genome 14, 142-148 (2004)

18. E. Merkureva, Genetic basis of breeding in animal husbandry (Moscow, 1977)

19. J. Tomka, K. Vašíčková, M. Oravcová, M. Bauer, J. Huba, D. Vašíček, D. Peškovičová, Mljekarstvo 66(2), 122-128 (2016) DOI: 10.15567/mljekarstvo.2016.0204

20. A. Trakovická, N. Moravčíková, T. Minarovič, A. Navrátilová, J. of Central European Agricult. 16(1), 65-75 (2015) DOI: 10.5513/JCEA01/16.1.1542

21. R.C. Chebel, F. Susca, J.E.P. Santos, J. of Dairy Sci. 91(7), 2893-2900 (2008)

22. N. Macciotta, M. Mele, G. Conte, J. of Dairy Sci. 91(8), 3184-3189 (2008)

23. M. Pozovnikova, G. Serdyuk, O. Tulinova, V. Terletskiy, N. Dementeva, O. Mitrofanova, Agricult. Biology 52(6), 1139-1147 (2017) DOI: 10.15389/agrobiology.2017.6.1139rus

24. J. Komisarek, Z. Dorynek, J. of Applied Genet. 50(2), 125-132 (2009)

25. P.M. Kgwatalala, E.M. Ibeagha-Awemu, A.F. Mustafa, X. Zhao, Animal Genet. 40, 609-615 (2009)

26. L.A. Clark, J.M. Thomson, S.S. Moore, M. Oba, Canad. J. of Animal Sci. 90, 575-584 (2010)

27. A. Schennink, J.M. Heck, H. Bovenhuis, M.H. Visker, H.J. Van Valenberg, J.A. Van Arendonk, J. of Animal Sci. 91, 2135-2143 (2008) 